\title{
Convective transport of very short lived bromocarbons to the stratosphere
}

\author{
Q. Liang ${ }^{1,2}$, E. Atlas ${ }^{3}$, D. Blake ${ }^{4}$, M. Dorf ${ }^{5, *}$, K. Pfeilsticker ${ }^{5}$, and S. Schauffler ${ }^{6}$ \\ ${ }^{1}$ NASA Goddard Space Flight Center, Atmospheric Chemistry and Dynamics, Greenbelt, MD, USA \\ ${ }^{2}$ Universities Space Research Association, GESTAR, Columbia, MD, USA \\ ${ }^{3}$ University of Miami, 4600 Rickenbacker Causeway, Miami, FL 33149, USA \\ ${ }^{4}$ University of California, 570 Rowland Hall, Irvine, CA 92697, USA \\ ${ }^{5}$ Institut für Umweltphysik, University of Heidelberg, Heidelberg, Germany \\ ${ }^{6}$ Earth Observing Laboratory, NCAR, Boulder, CO, USA \\ *now at: Max-Planck-Institut für Chemie, Mainz, Germany
}

Correspondence to: Q. Liang (qing.liang@nasa.gov)

Received: 26 November 2013 - Published in Atmos. Chem. Phys. Discuss.: 9 January 2014

Revised: 2 April 2014 - Accepted: 24 April 2014 - Published: 11 June 2014

\begin{abstract}
We use the NASA Goddard Earth Observing System (GEOS) Chemistry Climate Model (GEOSCCM) to quantify the contribution of the two most important brominated very short lived substances (VSLSs), bromoform $\left(\mathrm{CHBr}_{3}\right)$ and dibromomethane $\left(\mathrm{CH}_{2} \mathrm{Br}_{2}\right)$, to stratospheric bromine and its sensitivity to convection strength. Model simulations suggest that the most active transport of VSLSs from the marine boundary layer through the tropopause occurs over the tropical Indian Ocean, the tropical western $\mathrm{Pa}$ cific, and off the Pacific coast of Mexico. Together, convective lofting of $\mathrm{CHBr}_{3}$ and $\mathrm{CH}_{2} \mathrm{Br}_{2}$ and their degradation products supplies $\sim 8 \mathrm{ppt}$ total bromine to the base of the tropical tropopause layer (TTL, $\sim 150 \mathrm{hPa}$ ), similar to the amount of VSLS organic bromine available in the marine boundary layer $(\sim 7.8-8.4 \mathrm{ppt})$ in the active convective lofting regions mentioned above. Of the total $\sim 8 \mathrm{ppt}$ VSLS bromine that enters the base of the TTL at $\sim 150 \mathrm{hPa}$, half is in the form of organic source gases and half in the form of inorganic product gases. Only a small portion $(<10 \%)$ of the VSLS-originated bromine is removed via wet scavenging in the TTL before reaching the lower stratosphere. On average, globally, $\mathrm{CHBr}_{3}$ and $\mathrm{CH}_{2} \mathrm{Br}_{2}$ together contribute $\sim 7.7$ pptv to the present-day inorganic bromine in the stratosphere. However, varying model deep-convection strength between maximum (strongest) and minimum (weakest) convection conditions can introduce a $\sim 2.6$ pptv uncertainty in the contribution of VSLSs to inorganic bromine in the strato-
\end{abstract}

sphere $\left(\mathrm{Br}_{\mathrm{y}}^{\mathrm{VSLS}}\right)$. Contrary to conventional wisdom, the minimum convection condition leads to a larger $\mathrm{Br}_{\mathrm{y}}^{\mathrm{VSLS}}$ as the reduced scavenging in soluble product gases, and thus a significant increase in product gas injection (2-3 ppt), greatly exceeds the relatively minor decrease in source gas injection (a few 10ths ppt).

\section{Introduction}

Very short lived (VSL) bromocarbons originate mostly from ocean biogenic sources, and when transported into the stratosphere, they exert a significant impact on the bromine budget and stratospheric ozone depletion (Kurylo and Rodriguez, 1999; Sturges et al., 2000). Recent years have seen significant progress in modeling efforts to quantify the contribution of brominated VSL substances (VSLSs) to stratospheric inorganic bromine $\left(\mathrm{Br}_{\mathrm{y}}^{\mathrm{VSLS}}\right)$ (e.g., Warwick et al., 2006; Liang et al., 2010; Aschmann et al., 2011; Aschmann and Sinnhuber, 2013; Hossaini et al., 2012a, 2012b, 2013). These modeling studies suggest that brominated VSLSs contribute $4.8-7 \mathrm{ppt}$ to reactive stratospheric bromine, within the $1-8 \mathrm{ppt}$ estimate range from satellite and balloon-borne observations (WMO 2011; Sinnhuber et al., 2005; Sioris et al., 2006; Dorf et al., 2006a, 2008; Salawitch et al., 2010).

The most important VSLS pathway to the stratosphere is via convective lofting through the tropical tropopause layer 
(TTL). Atmospheric chemistry and transport of brominated VSLSs involves the coupling of various complex processes, e.g., highly un-uniform ocean emissions, convective transport of source gases and product gases, and wet scavenging of soluble product gases. An accurate modeling representation of these processes remains a challenging task. Modeling of these processes in general requires assumptions and/or parameterizations that have to some extent been simplified and may differ greatly from one model study to another. These differences have lead to significant differences in the modeled $\mathrm{Br}_{\mathrm{y}}^{\mathrm{VSLS}}$ estimates. For example, a recent model study by Hossaini et al. (2013) found that modeled $\mathrm{Br}_{\mathrm{y}}$ VSLS could vary by a factor of 2 when using four recently published emission inventories (Liang et al., 2010; Pyle et al., 2011; Ordóñez et al., 2012; Ziska et al., 2013). In general, model studies agree relatively well on source gas injection (SGI), suggesting that about $\sim 50 \%$ of bromoform $\left(\mathrm{CHBr}_{3}\right)$ and $\sim 90 \%$ of dibromomethane $\left(\mathrm{CH}_{2} \mathrm{Br}_{2}\right)$ can reach the stratosphere through SGI (e.g., Dvortsov et al., 1999; Nielsen and Douglass, 2001; Aschmann et al., 2011; Hossaini et al., 2010, 2012a). However, modeled contribution on product gas injection (PGI) is highly uncertain depending on how wet scavenging is implemented. Many early model studies assume a uniform washout lifetime against wet scavenging (e.g., Dvortsov et al., 1999; Nielsen and Douglass, 2001; Hossaini et al., 2010; Aschmann et al., 2009), which was inadequate and led to an underestimate in modeled $\mathrm{Br}_{\mathrm{y}} \mathrm{VSLS}$ (Hossaini et al., 2012a; Aschmann et al., 2011). A recent study by Aschmann and Sinnhuber (2013) shows that treating $\mathrm{Br}_{\mathrm{y}} \mathrm{VLS}$ as a single soluble tracer (e.g., Liang et al., 2010) can also lead to an underestimate. They found that $\mathrm{Br}_{\mathrm{y}}^{\mathrm{VSLS}}$ increased from 3.4 ppt to 5 ppt when switching from an idealized setup with a single soluble inorganic bromine tracer to a full chemistry scheme. Thus, an accurate modeling of transport and wet scavenging of PGI seems to be the key in narrowing the uncertainty of model estimate of $\mathrm{Br}_{\mathrm{y}}$ VSLS .

Understanding how the contribution of VSLSs to stratospheric bromine varies with convection strength has significant climate implications. A recent modeling analysis by Hossaini et al. (2012b) suggests that VSLS SGI will increase from $\sim 1.7 \mathrm{ppt}$ in 2000 to $\sim 2.0-2.7 \mathrm{ppt}$ in 2100 using the Intergovernmental Panel on Climate Change (IPCC) representative concentration pathways (RCPs) scenarios, as the future simulations feature stronger tropical deep convection transport to the lower stratosphere. On the other hand, the overall response of $\mathrm{Br}_{\mathrm{y}}^{\mathrm{VSLS}}$ to convection strength is somewhat murky. Earlier studies deploying a uniform washout lifetime found different washout rates result in a significant range in the contribution of $\mathrm{CHBr}_{3}$ to $\mathrm{Br}_{\mathrm{y}}, 0.5-3$ ppt in Sinnhuber and Folkins (2006) and 1.6-3 ppt in Aschmann et al., (2011). Liang et al. (2010), which deploys explicit wet scavenging in convective updrafts, found that convective scavenging only accounts for $\sim 0.2 \mathrm{ppt}$ difference in modeled $\mathrm{Br}_{\mathrm{y}}^{\mathrm{VSLS}}$. Similar results were reported in Aschmann et al. (2011), who showed that, while SGI is highly correlated with convective activity, the impact on total stratospheric bromine in a full chemistry scheme is nearly insensitive to dehydration, likely due to convection dilution and increased scavenging.

In this study, we use a three-dimensional chemistry climate model with fully interactive $\mathrm{CHBr}_{3}$ and $\mathrm{CH}_{2} \mathrm{Br}_{2}$, the two most important brominated VSLSs, to better understand how VSLSs and their degradation products enter the stratosphere. We will also test the uncertainty in modeled $\mathrm{Br}_{\mathrm{y}} \mathrm{VSLS}$ due to varying strength in convection and scavenging.

\section{Model and simulations}

\subsection{Model description}

We conduct model simulations using the NASA Goddard Earth Observing System (GEOS) Chemistry Climate Model (GEOSCCM) Version 2, which couples the GEOS-5 General Circulation Model (GCM) (Reinecker et al., 2008) with a stratospheric chemistry module. Model simulations have a horizontal resolution of $2.5^{\circ} \times 2^{\circ}$ (longitude by latitude) with 72 vertical layers from surface to $0.01 \mathrm{hPa}$. The GEOS5 model uses a flux-form semi-Lagrangian dynamical core (Lin, 2004) and the Relaxed Arakawa Schubert (RAS) parameterization for convection (Moorthi and Suarez, 1992). The GEOS-5 moist processes are represented using a convective parameterization and prognostic cloud scheme.

The GEOSCCM V2 stratospheric chemistry module includes all important gas phase stratospheric reactions as described in Douglass and Kawa (1999), and chemical calculations are carried out above the 27th eta layer (approximately $350 \mathrm{hPa}$ on average, globally). All chemical kinetics and photolysis rates are calculated following Jet Propulsion Laboratory (JPL) 2010 (Sander et al., 2011). We modify the standard V2 chemistry scheme to include $\mathrm{CHBr}_{3}$ and $\mathrm{CH}_{2} \mathrm{Br}_{2}$; both are interactive with the full stratospheric chemistry scheme. The two organic source gases are released at the ocean surface following the geographically resolved emission distribution described in Liang et al. (2010) and are destroyed in the atmosphere via photolysis and reaction with the hydroxyl radical $(\mathrm{OH})$. $\mathrm{OH}$ above $\sim 350 \mathrm{hPa}$ is calculated online in the stratospheric chemistry module. $\mathrm{OH}$ in the lowest 26 layers (troposphere) is relaxed to monthly mean climatological fields documented in Spivakovsky et al. (2000). Global annual mean $\mathrm{OH}$ from Spivakovsky et al. (2000) is $1.16 \times 10^{6}$ molecules $\mathrm{cm}^{-3}$, yielding an atmospheric methyl chloroform $\left(\mathrm{CH}_{3} \mathrm{CCl}_{3}\right)$ lifetime of $\sim 5.5$ years. In most of the troposphere, only simple bromine chemistry is considered; $80 \%$ of inorganic bromine products are classified as $\mathrm{HBr}$ and the remaining $20 \%$ as $\mathrm{HOBr}$ - ratios adopted from Yang et al. (2005). Above the 27th eta layer $(\sim 350 \mathrm{hPa})$, bromine from $\mathrm{CHBr}_{3}$ and $\mathrm{CH}_{2} \mathrm{Br}_{2}$ degradation is released as $\mathrm{Br}$ and interacts fully with stratospheric chemistry. Compare this to the idealized case in Liang et al. (2010) that tracks 
the atmospheric transport of $\mathrm{Br}_{\mathrm{y}}^{\mathrm{VSLS}}$ in a single highly soluble tracer, in this experiment, we deploy a detailed speciation of $\mathrm{Br}_{\mathrm{y}}^{\mathrm{VSLS}}$ in both soluble forms $\left(\mathrm{HBr}, \mathrm{HOBr}\right.$, and $\left.\mathrm{BrONO}_{2}\right)$ and insoluble forms $(\mathrm{Br}, \mathrm{BrO}$, and $\mathrm{BrCl})$ in the fully interactive stratospheric chemistry scheme in the TTL and stratosphere. Although $\mathrm{BrONO}_{2}$ is not produced in the troposphere in the current simple chemistry scheme, $\mathrm{BrONO}_{2}$ produced in the stratosphere is allowed to transport to lower altitudes via large-scale descent. A previous detailed tropospheric chemistry model study using the Harvard GEOSChem model and VSLS emissions from Liang et al. (2010) shows a small fraction of $\mathrm{Br}_{\mathrm{y}}$ exists as $\mathrm{BrO}(0.1-0.2 \mathrm{ppt})$ below $10 \mathrm{~km}$ in the tropics (Parrella et al., 2012). However, the impact of the absence of this tropospheric $\mathrm{BrO}$ on stratospheric bromine is likely small. No heterogeneous chemistry for VSLS is included in our simulations, but results from Aschmann and Sinnhuber (2013) suggest that the impact of heterogeneous chemistry is minor and that the inclusion of heterogeneous activation prevents loss in scavenging and can increase $\mathrm{Br}_{\mathrm{y}}^{\mathrm{VSLS}}$ by $10 \%$. While heterogeneous chemistry can shift $\mathrm{Br}_{\mathrm{y}}$ partition and increase $\mathrm{HBr}$ up to four times between 12 and $18 \mathrm{~km}$ in the tropics (Aschmann et al., 2011), the absence of heterogeneous chemistry in GEOSCCM is likely to have only a small impact on $\mathrm{Br}_{\mathrm{y}}^{\mathrm{VSLS}}$ since the model $\mathrm{HBr}$ is present in very low quantities during daytime when the majority of convective scavenging takes place (see Sect. 3.1 and Fig. 4) and the overall convective scavenging in the TTL is rather inefficient (see Sect. 3.2).

The wet scavenging of the soluble inorganic bromine is the same as that detailed in Liang et al. (2010). It includes scavenging in rainout (in-cloud precipitation) and washout (below-cloud precipitation) in both large-scale precipitation (Giorgi and Chameides, 1986) and deep convective updrafts (Balkanski et al., 1993). We assume high solubility for all three inorganic bromine reservoir species, $\mathrm{HBr}, \mathrm{HOBr}$, and $\mathrm{BrONO}_{2}$. At each time step, we follow the Giorgi and Chameides (1986) parameterization to compute the wet scavenging using the GEOS-5-model-calculated large-scale and convective precipitation rates and the parameterized fraction of grid square area, $F$, that actually experiences precipitation (Balkanski et al., 1993). Wet scavenging occurs only when air temperature is above $258 \mathrm{~K}$, following Giorgi and Chameides (1986). Previous studies using the Giorgi and Chameides (1986) parameterization showed that, for largescale precipitation, the global mean $F$ is about $2.5 \%$ for all grid boxes and the median value is $10 \%$, with values exceeding $40 \%$ in $\sim 10 \%$ of the grid boxes (Balkanski et al., 1993; Liu et al., 2001). The global mean $F$ for convective precipitation is much smaller, only $0.4 \%$ (Liu et al., 2001). When evaporation occurs during large-scale and convective transport, the corresponding fraction of the dissolved inorganic bromine is released back to the atmosphere. This wet scavenging scheme has been applied in many atmospheric modeling studies of soluble trace gases and aerosols, e.g., ${ }^{210} \mathrm{~Pb}$, ${ }^{7} \mathrm{Be}$, sulfate, sea salt, and dust, and the simulated concentra- tions compare well with surface observations at many observation sites around the globe (e.g., Balkanski et al., 1993; Chin et al., 2000; Ginoux et al., 2001; Liu et al., 2001).

In this study, we present results from two 51-year simulations between 1960 and 2010, one with brominated VSLSs chemistry ( $\left.R_{\mathrm{VSLS}}\right)$ and one without ( $\left.R_{\mathrm{BASE}}\right)$, to examine troposphere to stratosphere transport (TST) of VSLS and their contribution to stratospheric bromine. It takes a considerably long time ( $\sim 15$ years) for the full impact of VSLSs to reach the upper stratosphere; thus, the first 16 years are considered as spin-up. A full model evaluation and discussion of the impact of VSLSs on stratospheric ozone are presented in a separate paper, currently in preparation. For this study, we focus on model results of the two simulations from the last 10 years.

\subsection{Convection sensitivity simulations}

To quantify the uncertainty in $\mathrm{Br}_{\mathrm{y}}^{\mathrm{VSLS}}$ due to changes in convection strength, we conduct two sensitivity simulations from 1980 to 2010 to represent minimum convection $\left(R_{\mathrm{MINCNV}}\right)$ and maximum convection $\left(R_{\mathrm{MAXCNV}}\right)$ conditions by varying five convective parameters in RAS that impact the strength of deep convection, clouds, convective condensate, and re-evaporation (Ott et al., 2009, 2011). These five convective parameters are RASAL1 and RASAL2 (regulates the strength and vertical profile of the relaxation time scale for deep convection), ACRITFAC (used to compute the critical value of the cloud work function which determines the initiation of convection), BASE_EVAP_FAC (regulates the amount of rain evaporated into the environment below the cloud base), and AUTOC_CN (used to calculate the autoconversion of convective condensate). These five are identified as the most strongly influencing parameters out of the total of 16 parameters examined using a large number of "Monte Carlo" type simulations and ensemble simulations in both a single-column model as well as the GEOS-5 GCM (Ott et al., 2011). In the two sensitivity simulations, the five parameters are varied to produce the strongest (MAXCNV) and the weakest (MINCNV) representations of convection considered reasonable. In general, compared to the minimum convection condition, the maximum convection condition yields significantly large increases in shallow convection below $5 \mathrm{~km}$ and $\sim 20-30 \%$ stronger vertical mass flux and more horizontal divergence between 12.5 and $16.5 \mathrm{~km}$ (Ott et al., 2011). The values used for the five convective parameters for the minimum and maximum conditions have been tested extensively in the previous ensemble analysis. They produce reasonable precipitation patterns when compared with data from the Global Precipitation Climatology Project (GPCP) that were compiled from satellite and rain gauge observations (Ott et al., 2011). The correlation coefficients of the standard run, MAXCNV and MINCNV simulations, and the GPCP data sets are $0.65,0.64$, and 0.62 , respectively (Ott et al., 2011). 

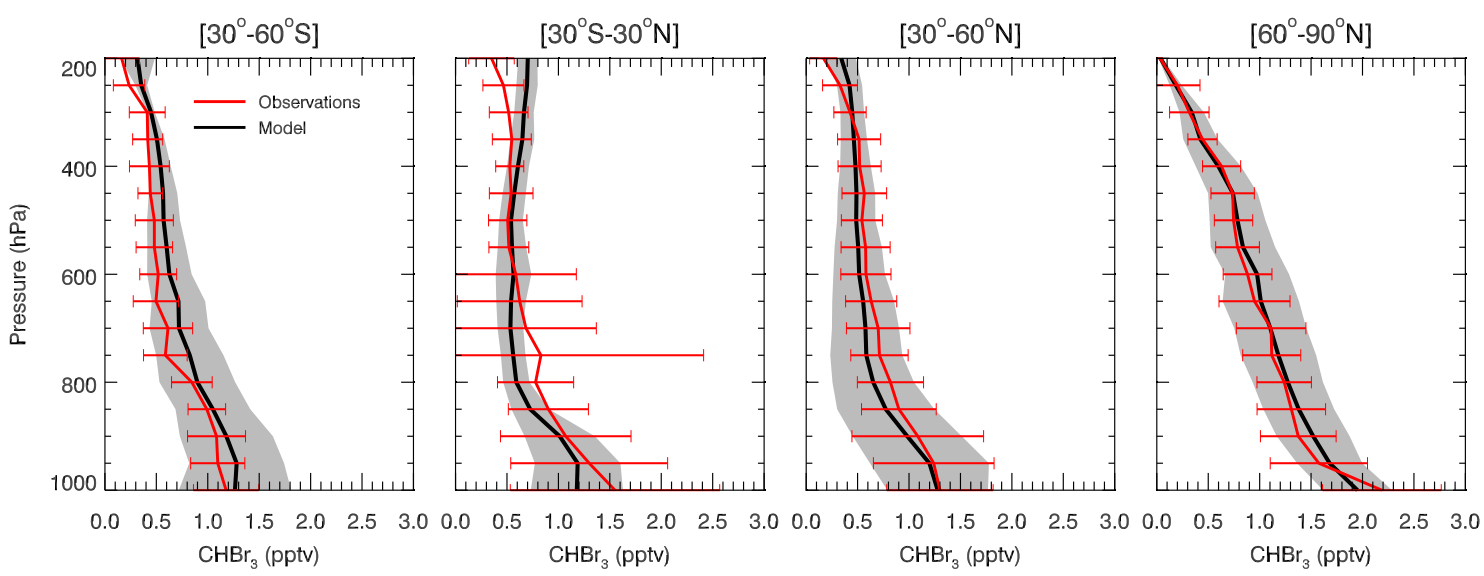

Figure 1. Comparison between the observed (red lines with horizontal bars indicating one standard deviation) and simulated (black lines with gray shading showing one sigma variability) vertical profiles of $\mathrm{CHBr}_{3}$ in the troposphere. Observations are compiled using whole air sampler canister measurements from eight NASA aircraft missions and are averaged for $30-60^{\circ} \mathrm{S}, 30^{\circ} \mathrm{S}-30^{\circ} \mathrm{N}, 30-60^{\circ} \mathrm{N}$, and $60-90^{\circ} \mathrm{N}$ latitude bands at $1 \mathrm{~km}$ vertical intervals. Model is sampled at the same location as the observations in the corresponding month in 2010.
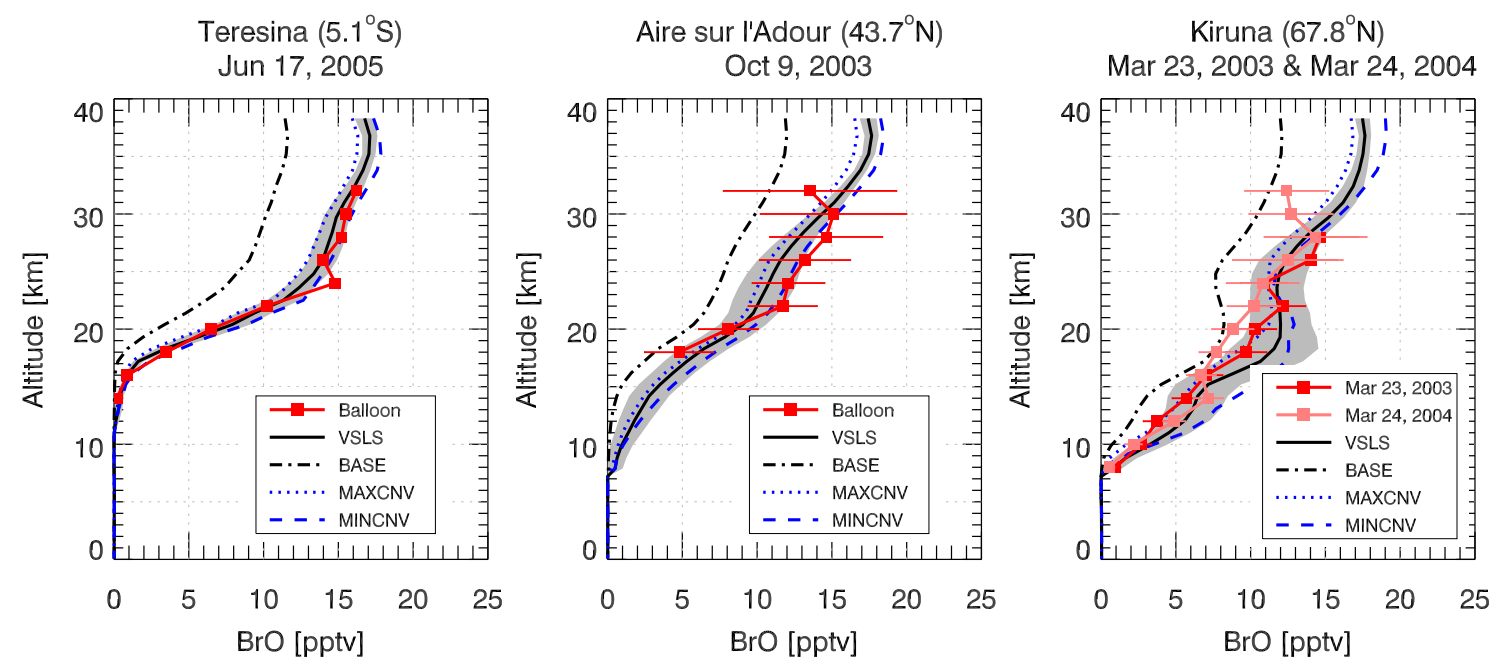

Figure 2. Comparison of simulated BrO from the GEOSCCM run $R_{\mathrm{VSLS}}$ (black solid line with one sigma variance in gray shading) with balloon measurements (red line with one sigma uncertainty in horizontal bars) from the LPMA/DOAS spectrometers in the stratosphere. The black dash-dotted line shows simulated BrO from the run without VSLS $\left(R_{\mathrm{BASE}}\right)$. Simulated BrO from the two convective sensitivity simulations is also shown (dotted line for maximum convection condition and dashed line for minimum convection condition). The model is sampled at the same month and latitude as the balloon measurements but only daytime profiles from all available longitude grid points are collected to calculate the one sigma variance of simulated BrO.

We aim to use these minimum and maximum conditions to bound the range of uncertainty that can be introduced due to variations in the strength of convection and wet scavenging.

\section{Results}

\subsection{The contribution of VSLSs to stratospheric bromine}

The simulated $\mathrm{CHBr}_{3}$ and $\mathrm{CH}_{2} \mathrm{Br}_{2}$ have been evaluated extensively in Liang et al. (2010) and compare well with aircraft and surface observations in their atmospheric distri- bution, geographically and vertically, as well as the associated seasonality. Here we present a summary comparison of observed and modeled $\mathrm{CHBr}_{3}$ in the troposphere for $30-60^{\circ} \mathrm{S}, 30^{\circ} \mathrm{S}-30^{\circ} \mathrm{N}, 30-60^{\circ} \mathrm{N}$, and $60-90^{\circ} \mathrm{N}$ latitude bands (Fig. 1). The observed profiles are compiled using whole air sampler canister measurements (Schauffler et al., 1999; Blake et al., 2003) from eight NASA aircraft missions, as detailed in Liang et al. (2010), and averaged within each latitude band at $1 \mathrm{~km}$ vertical intervals. The comparison clearly shows that the model captures well the source gas 


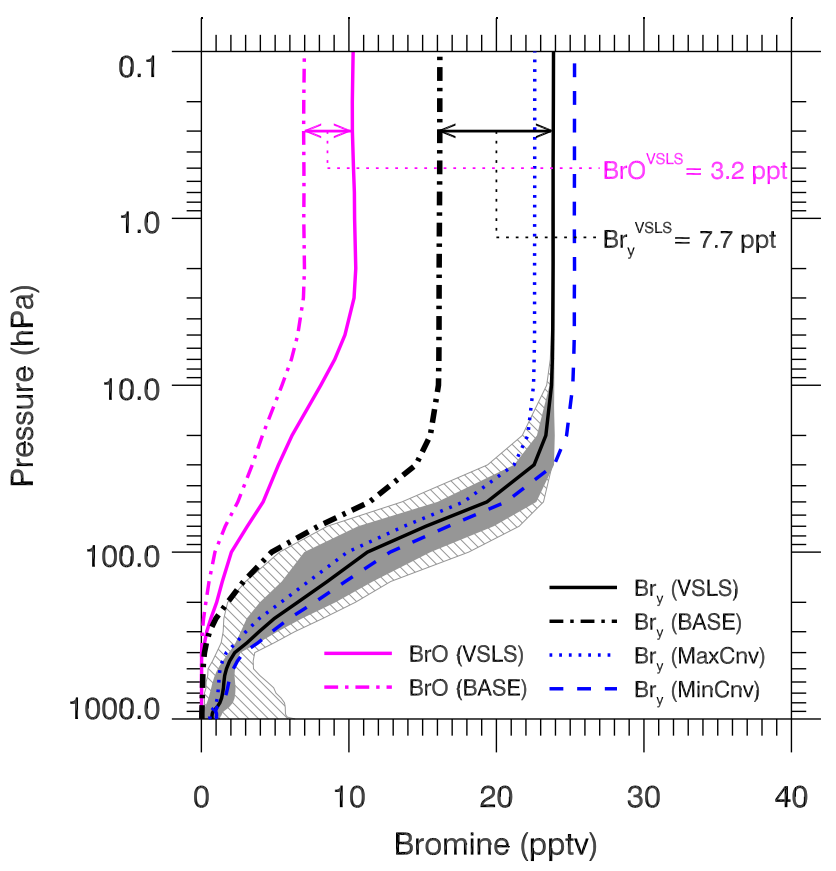

Figure 3. Model simulated global and annual mean $\mathrm{BrO}$ and $\mathrm{Br}_{\mathrm{y}}$ profiles from the simulation with VSLS ( $R_{\mathrm{VSLS}}$, solid lines) and the base simulation without VSLS ( $R_{\mathrm{BASE}}$, dash-dotted lines) for the year 2010. The gray shading indicates the spread of annual mean $\mathrm{Br}_{\mathrm{y}}$ in the $R_{\mathrm{VSLS}}$ run with the hatched areas indicating the minimum to maximum range and the solid shadings indicating one sigma variance. $\mathrm{Br}_{\mathrm{y}}$ from the two convective sensitivity simulations is also shown (blue dashed and dotted line for minimum and maximum convection conditions, respectively).

concentrations and vertical gradients in the tropics and mid and high latitudes in both hemispheres.

Figure 2 shows a comparison of our simulated $\mathrm{BrO}$ with balloon measurements from the LPMA (Limb Profile Monitor of the Atmosphere)/DOAS (differential optical absorption spectroscopy) at Teresina $\left(5.1^{\circ} \mathrm{S}\right)$, Aire sur l'Adour $\left(43.7^{\circ} \mathrm{N}\right)$, and Kiruna $\left(67.9^{\circ} \mathrm{N}\right)$ collected between 2003 and 2005 (Dorf et al., 2006a, b, 2008; Rozanov et al., 2011). The lower levels of $\mathrm{BrO}$ from $R_{\mathrm{BASE}}$ in comparison to the measurements indicate the essential role of VSLSs in completing the stratospheric bromine budget. With VSLSs, the GEOSCCM model simulates the observed $\mathrm{BrO}$ well at all sampled locations in the tropics and mid and high latitudes. Currently the GEOSCCM does not include the remaining three of the five major brominated VSLSs, $\mathrm{CH}_{2} \mathrm{BrCl}$, $\mathrm{CHBr}_{2} \mathrm{Cl}$, and $\mathrm{CHBrCl}_{2}$ (lifetimes between 70 and 150 days). Assuming a total tropospheric abundance of $1 \mathrm{ppt}$ of these three VSLSs and assuming that $\sim 90 \%$ (value for $\mathrm{CH}_{2} \mathrm{Br}_{2}$ ) of the source gases survive the TST to the stratosphere, this adds $\sim 0.9 \mathrm{ppt}$ to the current model estimate of stratospheric $\mathrm{Br}_{\mathrm{y}}$ of $\sim 24 \mathrm{ppt}$. With the current model $\mathrm{BrO} / \mathrm{Br}_{\mathrm{y}}$ ratio, such an increase will lead to an increase in $\mathrm{BrO}$ of up to $0.6 \mathrm{ppt}$ (not shown) in the stratosphere. This results in a better agreement with the DOAS BrO measurements in Teresina and Aire sur l'Adour and reasonable agreement at Kiruna, considering the large spatial variability in $\mathrm{BrO}$ in the high latitudes and rather localized balloon measurements. Since the model runs freely, with only surface source gas emissions being specified, the fact that the model simulates the observed concentrations for both the source gases and $\mathrm{BrO}$ well suggests that the model presents a credible representation of stratospheric bromine chemistry.

Comparing results from the $R_{\mathrm{VSLS}}$ and $R_{\mathrm{BASE}}$ runs (Fig. 3), we find that the inclusion of $\mathrm{CHBr}_{3}$ and $\mathrm{CH}_{2} \mathrm{Br}_{2}$ adds a uniform $\sim 7.7 \mathrm{ppt} \mathrm{Br}_{\mathrm{y}}$ throughout most of the stratosphere. The current $\mathrm{Br}_{\mathrm{y}}^{\mathrm{VSLS}}$ estimate is $55 \%$ higher than our previous estimate of $\sim 5 \mathrm{ppt}$ (Liang et al., 2010) and $\sim 6 \mathrm{ppt}$ estimate in Hossaini et al. (2013), though the latter two are driven by the same VSLS emissions. Compared to the idealized case in Liang et al. (2010) that tracks $\mathrm{Br}_{\mathrm{y}}^{\mathrm{VSLS}}$ in a single highly soluble tracer, $\mathrm{Br}_{\mathrm{y}}^{\mathrm{VSLS}}$ in this study is present in the fully interactive stratospheric chemistry scheme in both soluble forms $\left(\mathrm{HBr}, \mathrm{HOBr}\right.$, and $\left.\mathrm{BrONO}_{2}\right)$ and insoluble forms $(\mathrm{Br}, \mathrm{BrO}$, and $\mathrm{BrCl})$ in the TTL. The ratio of insoluble and soluble $\mathrm{Br}_{\mathrm{y}}$ varies with the time of day as well as altitude and location. Figure 4 shows the contrast of model inorganic bromine speciation in the tropics between daytime and nighttime. In the TTL region, at daytime, when most convective lofting occurs, the majority of $\mathrm{Br}_{\mathrm{y}}$ exists as insoluble $\mathrm{Br}$ and $\mathrm{BrO}$ (Fig. 4a), therefore greatly increasing the amount of $\mathrm{Br}_{\mathrm{y}}^{\mathrm{VSLS}}$ that survives wet scavenging during the TST and ultimately reaches the stratosphere. The increase from $\sim 5 \mathrm{ppt}$ to $\sim 7.7 \mathrm{ppt}$ when switching from an idealized case to fully interactive stratospheric chemistry is consistent with results from Aschmann and Sinnhuber (2013), who found that $\mathrm{Br}_{\mathrm{y}}^{\mathrm{VSLS}}$ increased from $3.4 \mathrm{ppt}$ to $5 \mathrm{ppt}$ when switching from an idealized setup with a single soluble inorganic bromine tracer to a full chemistry scheme. The different estimates between Hossaini et al. (2013) and this work are likely due to how the ratio of soluble and insoluble inorganic bromine is determined in the two models. Compared to this work which partitions inorganic bromine in its various forms based on chemical reaction rates, Hossaini et al. (2013) used a mean altitude-dependent $\mathrm{HBr}: \mathrm{Br}_{\mathrm{y}}$ ratio. This likely leads to an excessive washout of $\mathrm{Br}_{\mathrm{y}}^{\mathrm{VSLS}}$, as, during daytime, when most of the convective lofting occurs, the majority of the inorganic bromine exists as insoluble $\mathrm{Br}$ and $\mathrm{BrO}$. This suggests that a close approximation of soluble and insoluble inorganic product gases and the associated diurnal variation are critical to accurately quantify the contribution of VSLSs to stratospheric halogen in VSLS modeling.

A recent study by Kreycy et al. (2013), using balloonborne DOAS $\mathrm{BrO}$ measurements over Kiruna $\left(67.9^{\circ} \mathrm{N}\right.$, $\left.22.1^{\circ} \mathrm{E}\right)$, suggests that the ratio of $J\left(\mathrm{BrONO}_{2}\right) / k_{\mathrm{BrO}+\mathrm{NO}_{2}}$ should be larger than the JPL 2010 recommendations by a factor of 1.7 and is likely to shift more $\mathrm{BrONO}_{2}$ into $\mathrm{BrO}$. However, this result will only have a small impact on 
a) daytime $\left[30^{\circ} \mathrm{N}-30^{\circ} \mathrm{S}\right]$

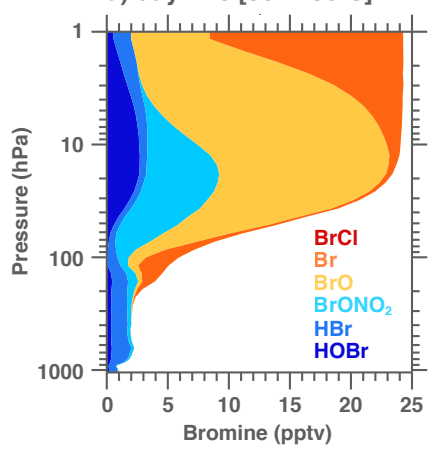

b) nighttime $\left[30^{\circ} \mathrm{N}-30^{\circ} \mathrm{S}\right]$

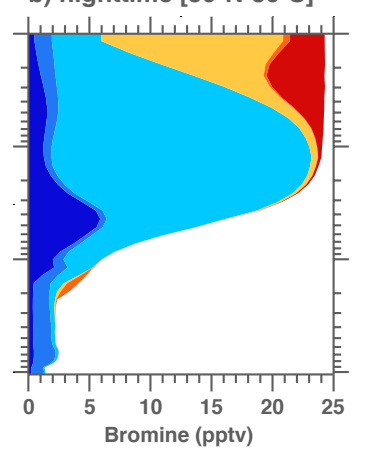

Figure 4. Annual mean model inorganic bromine $(\mathrm{BrCl}, \mathrm{Br}, \mathrm{BrO}$, $\mathrm{BrONO}_{2}, \mathrm{HBr}, \mathrm{HOBr}$ ) tropical vertical profiles for daytime (left panel) and nighttime (right panel), averaged between $30^{\circ} \mathrm{N}$ and $30^{\circ} \mathrm{S}$.

our $\mathrm{Br}_{\mathrm{y}}^{\mathrm{VSLS}}$ estimates. Currently, $\mathrm{BrONO}_{2}$ only accounts for $\sim 0.5$ ppt of the total $\mathrm{Br}_{\mathrm{y}}^{\mathrm{VSLS}}$ in the TTL during daytime. In addition, convective scavenging of the inorganic bromine in the TTL is not an efficient removal process (section 3.2). Increasing the ratio of $J\left(\mathrm{BrONO}_{2}\right) / k_{\mathrm{BrO}}+\mathrm{NO}_{2}$ in the model will shift $\mathrm{Br}_{\mathrm{y}}^{\mathrm{VSLS}}$ partition from $\mathrm{BrONO}_{2}$ to $\mathrm{BrO}$, which in turn will result in an increase in $\mathrm{Br}_{\mathrm{y}}^{\mathrm{VSLS}}$ due to less $\mathrm{BrONO}_{2}$ scavenging. However, this increase will be small (at most a few tenths ppt).

\subsection{Troposphere-to-stratosphere transport of VSLSs}

We use the simulated monthly mean $\mathrm{CHBr}_{3}$ distribution on the $355 \mathrm{~K}$ potential temperature surface (just below the TTL) to show the important tropical regions where active TST initiates (Fig. 5). Theoretically, trace gas distribution on the 365 $\mathrm{K}$ surface should be more indicative of TST as $365 \mathrm{~K}$ marks zero radiative heating, and air mass elevated above this level can enter the lower stratosphere through slow radiative ascent (e.g., Gettelman and Forster, 2002; Fueglistaler et al., 2009). However, it is difficult to identify active TST regions on the $365 \mathrm{~K}$ map (not shown) as a significant portion of $\mathrm{CHBr}_{3}$ is converted to product gases. This is not surprising for a short-lived compound with a lifetime of $\sim 26$ days (WMO 2011), while it takes about 10 days, on average, for air to travel $\pm 10 \mathrm{~K}$ (Fueglistaler et al., 2004; Levine et al., 2007). Compared to $\mathrm{CHBr}_{3}$, it is much more difficult to identify active TST regions on a $\mathrm{CH}_{2} \mathrm{Br}_{2}$ map, as $\mathrm{CH}_{2} \mathrm{Br}_{2}$ distribution appears more zonal with a smaller meridional gradient due to a longer lifetime of $\sim 120$ days (WMO 2011) and up to $\sim 450$ days locally in the TTL (Hossaini et al., 2010) and thus more mixing with the surrounding background air (not shown). The $355 \mathrm{~K} \mathrm{CHBr}_{3}$ map shows three active regions that can efficiently deliver VSLSs to the base of the TTL: (1) the tropical Indian Ocean, (2) the tropical western Pacific, and (3) the area off the Pacific coast of Mexico (Fig. 5). There is significant seasonality associated with each entry re-

gion. The Indian Ocean appears as the most active region for the TST of $\mathrm{CHBr}_{3}$ and occurs all year long with a maximum in boreal winter (DJF). Lofting in the tropical western Pacific reaches its maximum in boreal summer (JJA), while the TST off the Mexico coast occurs mostly in boreal summer (JJA) and fall (SON). The importance of convective lofting in the western Pacific warm pool in TST has been noted in many previous studies (e.g., Hatsushika and Yamazaki, 2003; Fueglistaler et al., 2004; Aschmann et al., 2009; Hossaini et al., 2012a; Ashfold et al., 2012), with several others suggesting that the Indian Ocean is also an important region in the TST of VSLSs (Levine et al., 2007, 2008; Brioude et al., 2010; Hoyle et al., 2011).

We show in Fig. 6 the vertical profiles of organic source gases $\left(\mathrm{CH}_{2} \mathrm{Br}_{2} \times 2, \mathrm{CHBr}_{3} \times 3\right)$ and inorganic product gases in the three critical convective lofting regions to illustrate the transport and wet scavenging of the brominated VSLSs during the TST and the relative importance of SGI vs. PGI. Although tropospheric $\mathrm{Br}_{\mathrm{y}}$ is assumed to be highly soluble, only a fraction of the grid boxes and a fractional area of the precipitating grid boxes actually experience precipitation and scavenging. On average, of all inorganic bromine ( $\sim 4 \mathrm{ppt}$ ) produced from $\mathrm{CHBr}_{3}$ and $\mathrm{CH}_{2} \mathrm{Br}_{2}$ in the tropical troposphere, about $50 \%$ ( 2 ppt) is removed below $500 \mathrm{hPa}$, mainly by large-scale precipitation (Liang et al., 2010), with an additional few tenths ppt scavenged in the upper troposphere. Together, $\sim 1.5 \mathrm{ppt}$ of $\mathrm{HBr}$ and $\mathrm{HOBr}$ survive largescale and convective scavenging and remain in the tropical upper troposphere. $\mathrm{Br}, \mathrm{BrO}$, and $\mathrm{BrONO}_{2}$ produced from $\mathrm{CHBr}_{3}$ and $\mathrm{CH}_{2} \mathrm{Br}_{2}$ degradation in the tropical upper troposphere adds an additional $\sim 2 \mathrm{ppt}$ to $\mathrm{Br}_{\mathrm{y}}^{\mathrm{VSLS}}$. Over the tropical Indian Ocean, on average annually, the mixing ratio of total bromine from VSLS (organic + inorganic) at $150 \mathrm{hPa}$ $(\sim 355 \mathrm{~K})$ is $\sim 8.5 \mathrm{ppt}$, the same as its surface abundance $(\sim 8.5 \mathrm{ppt})$. This implies that convective lofting in this region is so efficient that the amount of VSL bromine that enters the base of the TTL is set by the concentration at the marine boundary layer. As air ascends to higher altitudes, a small portion of $\mathrm{Br}_{\mathrm{y}}^{\mathrm{VSLS}}(\sim 0.8 \mathrm{ppt}, 10 \%)$ is gradually removed from the atmosphere via wet scavenging until it reaches a constant $7.7 \mathrm{ppt}$ above $10 \mathrm{hPa}$. Results from the tropical western Pacific and off the coast of Mexico are similar, with a smaller surface abundance of organic bromine (7.8 8.1 ppt) and slightly less washout around $100 \mathrm{hPa}$. The global averaged total bromine from the VSLS (Br ${ }^{\mathrm{VSLS}}$ ) profile shows a maximum value of $\sim 8 \mathrm{ppt}$ at $\sim 100 \mathrm{hPa}$. To supply this amount of $\mathrm{Br}^{\mathrm{VSLS}}$ to the lower stratosphere, transport from the marine boundary layer has to initiate from tropical regions where active convective lofting is colocated with high surface concentrations where the collective $\mathrm{CHBr}_{3}$ and $\mathrm{CH}_{2} \mathrm{Br}_{2}$ abundance exceeds 8 ppt $\mathrm{Br}$.

Mapping streamlines onto the VSLS organic bromine distribution in the tropics clearly illustrates the importance of the colocation of deep convection with high surface concentration regions (Fig. 7). Among the three ascending branches 

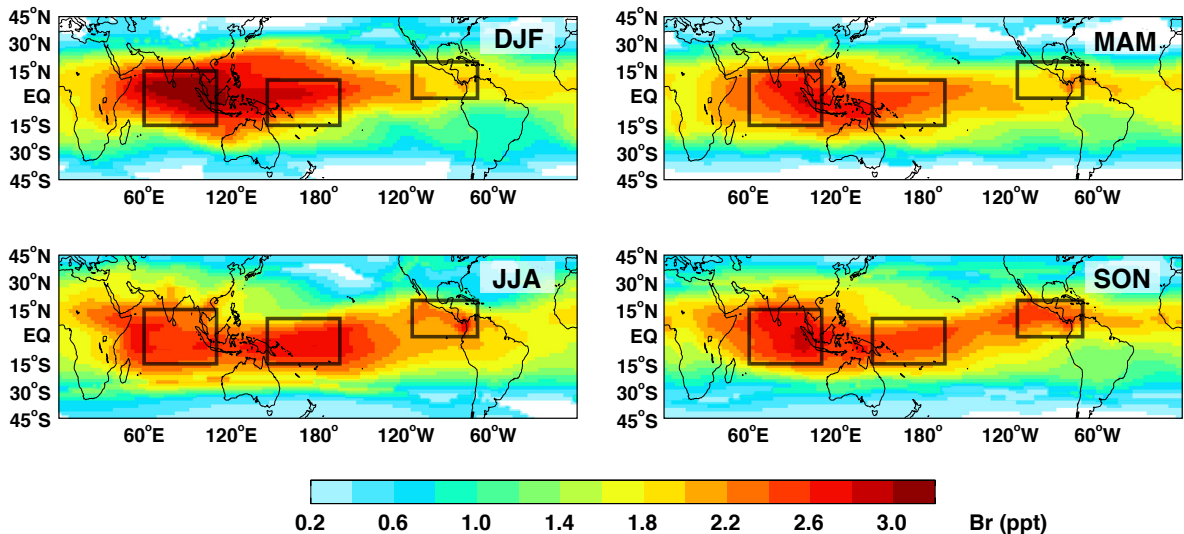

Figure 5. 10-year averaged (2001-2010) seasonal mean distribution of simulated $\mathrm{CHBr}_{3}$ (unit: ppt $\mathrm{Br}$ ) at the $355 \mathrm{~K}$ potential temperature layer (just below the tropopause) in DJF, MAM, JJA, and SON. The black boxes outline the three regions where most of the active troposphere-to-stratosphere transport occurs.

(a) $\left[15^{\circ} \mathrm{S}-15^{\circ} \mathrm{N}, 60^{\circ} \mathrm{E}-110^{\circ} \mathrm{E}\right]$

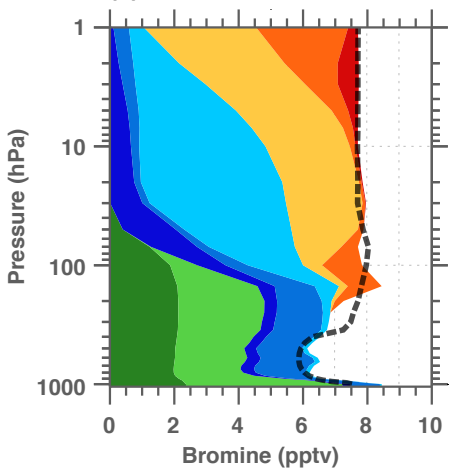

(b) $\left[15^{\circ} \mathrm{S}-10^{\circ} \mathrm{N}, 145^{\circ} \mathrm{E}-15^{\circ} \mathrm{W}\right]$

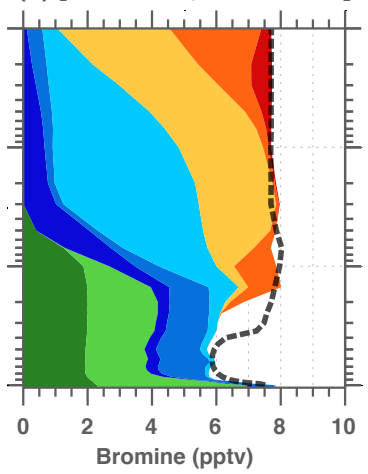

(c) $\left[\mathrm{EQ}-20^{\circ} \mathrm{N}, 85^{\circ} \mathrm{W}-70^{\circ} \mathrm{W}\right]$

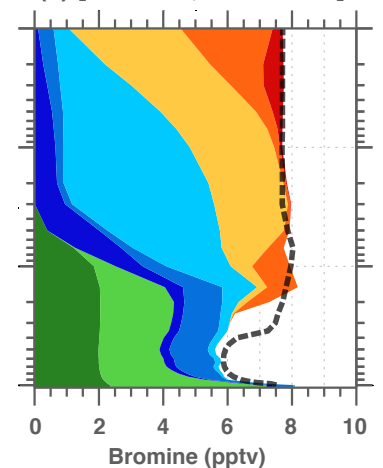

$\mathrm{BrCl}$

$\mathrm{Br}$

BrO

$\mathrm{BrONO}_{2}$

$\mathrm{HBr}$

$\mathrm{HOBr}$

$3 \times \mathrm{CHBr}_{3}$

$2 \times \mathrm{CH}_{2} \mathrm{Br}_{2}$

Figure 6. The contribution of organic bromine $\left(\mathrm{CH}_{2} \mathrm{Br}_{2} \times 2, \mathrm{CHBr}_{3} \times 3\right)$ and inorganic bromine $\left(\mathrm{Br}_{\mathrm{y}} \mathrm{VSLS}\right)$ from $\mathrm{CHBr}_{3}$ and $\mathrm{CH}_{2} \mathrm{Br}_{2}$ degradation to atmospheric bromine in three active TST regions: (a) the tropical Indian Ocean (left), (b) the tropical western Pacific warm pool (middle), and (c) the Pacific coast of Mexico (right). The soluble product gases $\left(\mathrm{HBr}, \mathrm{HOBr}, \mathrm{BrONO}_{2}\right)$ and insoluble product gases $(\mathrm{Br}$, $\mathrm{BrO}$, $\mathrm{BrCl})$ are shown in blue shades and red and yellow shades, respectively. The global mean sum of organic and inorganic bromine from VSLSs is also shown (thick black dashed line). The model results are 10-year annual averages from 2001 to 2010.

of the Walker circulation (Webster, 1983), ascent in the tropical western Pacific penetrates deepest into the TTL, but ascent in the Indian Ocean is capable of delivering more VSLS bromine to the base of the TTL due to higher surface concentrations. The surface abundance of VSLS bromine is largely dependent on the emission distribution used. Liang et al. (2010) assumed uniform zonal emission strength across all longitudes, but the rate of bromocarbon emissions for the coastal regions per unit area is much higher than that in the open oceans. In the tropics, the prevailing surface easterly trade winds tend to bring recent emissions of $\mathrm{CHBr}_{3}$ from the adjacent Indonesian coastal regions while the tropical western Pacific Ocean sees recent emissions of $\mathrm{CHBr}_{3}$ from the open ocean. Therefore, the surface concentrations are higher in the Indian Ocean than the tropical western Pacific. However, it is important to point out that only a few surface observation constraints from the tropical western Pacific and none from the tropical Indian Ocean were available to derive the Liang et al., (2010) emission scenario. Hossaini et al. (2013) conducted a recent model study comparing four independent brominated VSLS emission estimates. Of all four emission inventories examined (Liang et al., 2010; Pyle et al., 2011; Ordóñez et al., 2012; Ziska et al., 2013), modeled $\mathrm{CHBr}_{3}$ and $\mathrm{CH}_{2} \mathrm{Br}_{2}$ concentrations using the emission estimates from Liang et al. (2010) compare very well against tropical observations from multiple years of National Oceanic and Atmospheric Administration/Earth System Research Laboratory (NOAA/ESRL) surface flask measurements. The global mean model biases (model - observations) are $-0.25 \mathrm{ppt}$ for $\mathrm{CHBr}_{3}$ (ranging from $+0.12 \mathrm{ppt}$ in the tropics to $-0.65 \mathrm{ppt}$ in the northern high latitudes) and $-0.02 \mathrm{ppt}$ for $\mathrm{CH}_{2} \mathrm{Br}_{2}$ (ranging from $+0.14 \mathrm{ppt}$ in the tropics to $-0.11 \mathrm{ppt}$ in the northern and southern high latitudes). Comparison with the High-performance Instrumented Airborne Platform for 


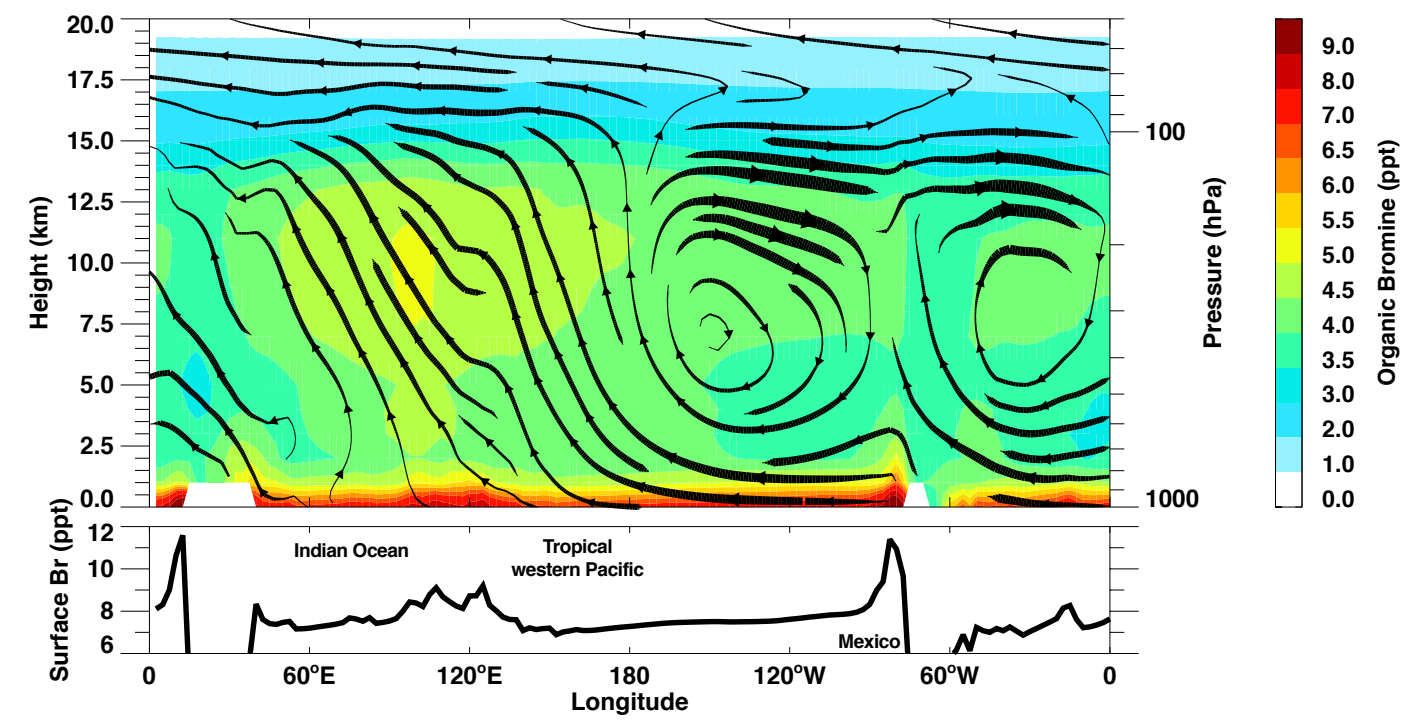

Figure 7. Longitude-height cross section of modeled total VSL organic bromine $\left(\mathrm{CHBr}_{3} \times 3+\mathrm{CH}_{2} \mathrm{Br}_{2} \times 2\right)$ (color contours) and streamlines (black lines) in the deep tropics. The organic bromine and wind streams are 10-year annual averages $(2001-2010)$ between $10^{\circ} \mathrm{S}$ and $10^{\circ} \mathrm{N}$. Surface organic bromine abundance is shown as the black solid graph at the bottom panel.

Environmental Research (HIAPER) Pole-to-Pole Observations (HIPPO) measurements between 2009 and 2011 supported by the National Science Foundation (NSF) yields even better agreement, with little biases in global mean $\mathrm{CHBr}_{3}\left(\Delta_{\text {model-obs }}=+0.04 \mathrm{ppt}\right)$ and $\mathrm{CH}_{2} \mathrm{Br}_{2}\left(\Delta_{\text {model-obs }}=\right.$ $-0.01 \mathrm{ppt})$. The modeled biases for each latitude band are also small, $-0.16-+0.30$ ppt for $\mathrm{CHBr}_{3}$ and $-0.10-$ $+0.12 \mathrm{ppt}$ for $\mathrm{CH}_{2} \mathrm{Br}_{2}$. When compared to the aircraft measurements collected in the tropical western Pacific during the Stratospheric Ozone: Halogen Impacts in a Varying Atmosphere (SHIVA) campaign, Liang et al. (2010) yields the best $\mathrm{CH}_{2} \mathrm{Br}_{2}$ (mean bias of +0.2 ppt compared with observations), compared to the other three emissions, but the simulated $\mathrm{CHBr}_{3}$ is, on average, $\sim+0.76 \mathrm{ppt}$ too high on average. Note that the high bias in modeled $\mathrm{CHBr}_{3}$ in the tropical western Pacific will likely lead to a high bias in the model $\mathrm{Br}_{\mathrm{y}}^{\mathrm{VSLS}}$, although the lofting in the Indian Ocean seems to be more critical in determining the total amount of VSLS bromine in the lower stratosphere in this study. The modelsimulated high concentration of brominated VSLS over the Indian Ocean is yet to be evaluated when more surface observations become available, and the importance of the Indian Ocean in delivering higher amounts of VSLS bromine into the TTL needs to be assessed. The simulated high surface concentrations of $\mathrm{CHBr}_{3}$ and $\mathrm{CH}_{2} \mathrm{Br}_{2}$ near tropical Central America were validated with the NASA Tropical Composition, Clouds, and Climate Coupling (TC4) and Intercontinental Chemical Transport Experiment - Phase B (INTEX-B) measurements (Liang et al., 2010). This region, compared to the above two, is much less efficient in delivering VSLS bromine into the TTL due to the relatively weaker ascent. However, this ascending branch can be important in particu- lar seasons and in individual years as the Walker circulation moves in the east-west direction between different phases of the El Niño Southern Oscillation (ENSO). For example, using trajectory calculations, Levine et al. (2008) found a clear shift in the TTL air origin from the tropical western Pacific and Indonesia to those from the eastern Pacific and South America in El Niño years.

Of the total VSLS bromine that enters the base of the TTL, about half $(\sim 4 \mathrm{ppt})$ is in the form of inorganic product gases (Fig. 6) despite our simple assumption that all inorganic bromine reservoir species are highly soluble and all inorganic bromine produced below $350 \mathrm{hPa}$ is classified as the soluble forms $\mathrm{HBr}$ and $\mathrm{HOBr}$. A commonly adopted approach in many previous modeling studies is to prescribe the VSLS concentration at the base of the TTL with observed organic source gas mixing ratios in the upper troposphere and track the subsequent chemistry and transport (e.g., Sinnhuber and Folkins, 2006; Aschmann et al., 2011; Aschmann and Sinnhuber, 2013). Our result implies that the $\mathrm{Br}_{\mathrm{y}}^{\mathrm{VSLS}}$ estimate from such approach is not complete as it lacks an important component associated with PGI, which is as large as SGI at the base of the TTL in our model simulation. A second implication of this result is that, if we were to use measurements from the TTL region to quantify the contribution of VSLSs to stratospheric bromine, it is necessary to make measurements of both organic and inorganic forms to fully account for the impact of VSLSs on the atmospheric bromine budget.

\subsection{The Impact of Convection Strength}

We examine the difference between the two convection sensitivity simulations, $R_{\mathrm{MINCNV}}$ and $R_{\mathrm{MAXRUN}}$, to illustrate the 
MinCnv - MaxCnv: 355K - 380K
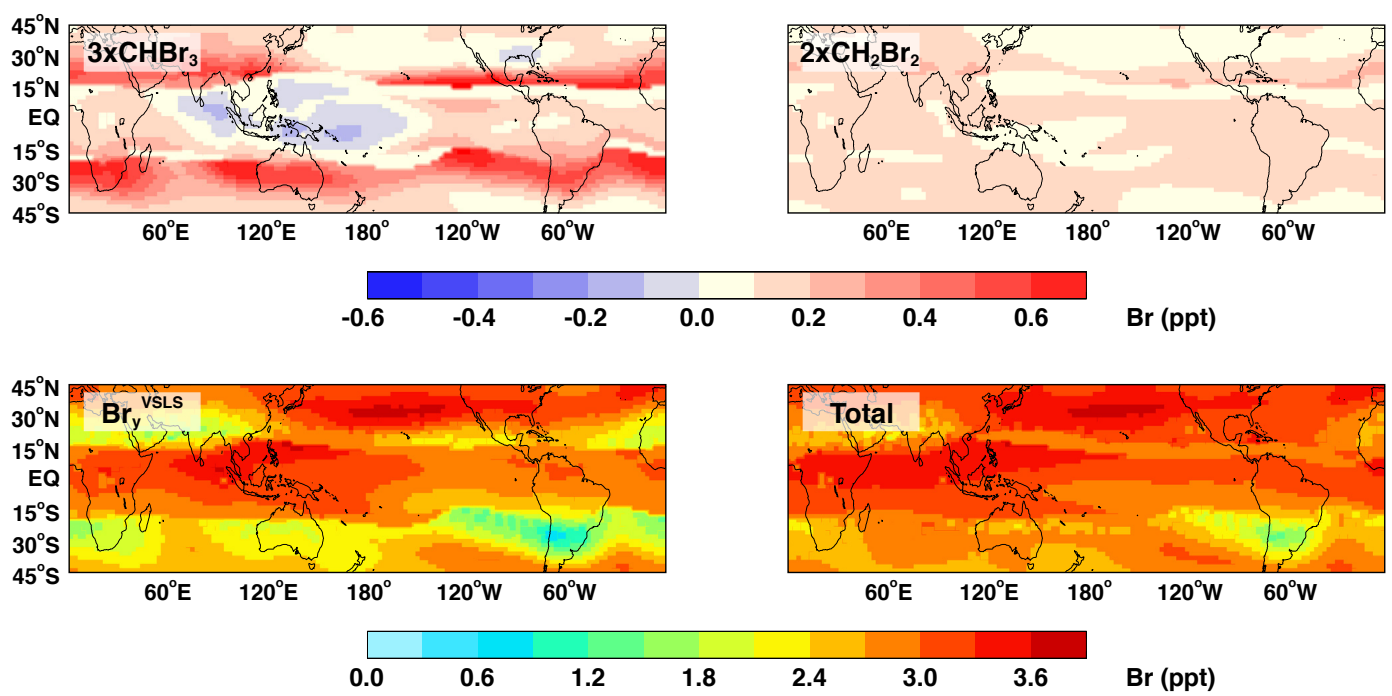

Figure 8. The simulated annual mean difference between the $R_{\mathrm{MINCNV}}$ and $R_{\mathrm{MAXRUN}}$ runs in organic bromine $\left(3 \times \mathrm{CHBr}_{3}, 2 \times \mathrm{CH}_{2} \mathrm{Br}_{2}\right)$, inorganic bromine, and total bromine from VSLSs between 355 and $380 \mathrm{~K}$. The model results are 10 -year annual averages from 2001 to 2010 .

impact of deep convection on $\mathrm{Br}_{\mathrm{y}}^{\mathrm{VSLS}}$ (Fig. 8). The difference between these two simulations $\left(R_{\mathrm{MINCNV}}-R_{\mathrm{MAXRUN}}\right)$ suggests that in the regions that mattered most (the three tropical convection centers), surprisingly, the minimum convection condition is more favorable for the TST of VSLSs. While weaker convection slightly decreases SGI (by a few tenths ppt), PGI increases significantly (by 2-3 ppt) due to less scavenging under the minimum convection condition. The TST of the longer-lived $\mathrm{CH}_{2} \mathrm{Br}_{2}$ is less sensitive to convection strength compared to that of $\mathrm{CHBr}_{3}$ because of its longer lifetime. The significant increase in $\mathrm{CHBr}_{3}$ and $\mathrm{CH}_{2} \mathrm{Br}_{2}$ in the mid-latitude bands under minimum convection mainly reflects the compensating responses in largescale descent in a general circulation model as a result of changing convection strength (Ott et al., 2011). The decrease of the descent does not impact the TST of VSLSs. Aschmann et al. (2011) found a qualitatively similar behavior for changes of VSLS SGI and PGI under El Niño vs. La Niña conditions - while SGI increased slightly under enhanced deep convection, the sum of SGI and PGI decreased. However, the net decrease in the $\mathrm{Br}_{\mathrm{y}}^{\mathrm{VSLS}}(<0.5 \mathrm{ppt})$ due to changes in convection strength between El Niño vs. La Niña conditions reported in Aschmann et al. (2011) is much smaller than our results above, most likely due to a much higher $\mathrm{Br}_{\mathrm{y}}^{\mathrm{VSLS}}$ abundance in the TTL in this work.

Globally, the differences in convection strength and wet scavenging introduce a $\sim 2.6 \mathrm{ppt}$ uncertainty into $\mathrm{Br}_{\mathrm{y}}^{\mathrm{VSLS}}$ ( $\sim 6.5 \mathrm{ppt}$ in $R_{\text {MAXRUN }}$ and $\sim 9.1 \mathrm{ppt}$ in $R_{\text {MINRUN }}$ ) (Fig. 3 ). Although these two simulations represent the two extreme parameterization conditions within a reasonable range, $\mathrm{BrO}$ from both simulations still falls within the uncertainty range of the DOAS balloon observations of $\pm 2.5 \mathrm{ppt}$ (Fig. 2; Dorf et al., 2006b).

\section{Conclusions}

We use the NASA Goddard 3-D Chemistry Climate Model, GEOSCCM, to quantify the contribution of brominated very short-lived substances (VSLSs) to reactive stratospheric bromine and to test its sensitivity to the strength of deep convection and the associated scavenging.

The inclusion of $\mathrm{CHBr}_{3}$ and $\mathrm{CH}_{2} \mathrm{Br}_{2}$ in a fully interactive stratospheric chemistry module deployed in the tropical tropopause layer (TTL) and the stratosphere adds $\sim 7.7 \mathrm{pptv}$ to the present-day stratospheric inorganic bromine. The most active transport of VSLSs from the marine boundary layer through the TTL occurs where high surface concentrations of VSLSs are colocated with deep convection centers: (1) the tropical Indian Ocean, (2) the tropical western Pacific warm pool, and (3) off the Pacific coast of Mexico. On average, annually, almost all VSLS-originated bromine available in the marine boundary layer $(\sim 7.8-8.4 \mathrm{ppt})$ at these active convective lofting regions enters the TTL, half of it in the form of source gas injection (SGI) and half of it in the form of product gas injection (PGI). After lofting above $150 \mathrm{hPa}$ $(\sim 355 \mathrm{~K})$, the majority of the VSLS-originated bromine survives TST and reaches the lower stratosphere, with only a small portion $(\sim 0.8 \mathrm{ppt}, 10 \%)$ removed by wet scavenging. Our model results point to a clear need for more surface measurements in the active VSLS lofting regions, in particular the tropical Indian Ocean and the tropical western Pacific, for an improved emissions estimate as well as a better 
quantification of how much VSLS bromine is available before it ultimately enters the stratosphere through the TTL.

Our current estimate of the contribution of $\mathrm{CHBr}_{3}$ and $\mathrm{CH}_{2} \mathrm{Br}_{2}$ to stratospheric bromine $\left(\mathrm{Br}_{\mathrm{y}}^{\mathrm{VSLS}}\right)$ is higher than previous modeling estimates, mainly reflecting the differences in how transport and wet scavenging of product gases are treated in different models (Hossaini et al., 2012a; Aschmann and Sinnhuber, 2013). Interestingly, even though the models are driven with the same emission estimates (Liang et al., 2010; Hossaini et al., 2013) and/or with similar source gas abundance at the base of the TTL (Aschmann et al. 2011; Aschmann and Sinnhuber, 2013), this study still yields higher $\mathrm{Br}_{\mathrm{y}}^{\mathrm{VSLS}}$ for two main reasons. Modeling VSLSs and their degradation products in a full stratospheric chemistry scheme in the TTL and stratosphere leads to a better representation of the partition between soluble and insoluble product gases and the associated diurnal variation; both are critical in an accurate $\mathrm{Br}_{\mathrm{y}}^{\mathrm{VSLS}}$ estimate. Secondly, tracking PGI from the free troposphere to the base of the TTL, which is as large as SGI at the base of the TTL in our model simulation, is also important. This was not included in many earlier model studies (e.g., Aschmann et al., 2011; Aschmann and Sinnhuber, 2013), thus implying a missing component in these earlier model VSLS contribution estimates.

Differences in model deep-convection strength can introduce $\sim 30 \%(6.6-9.2 \mathrm{ppt})$ uncertainty in simulated $\mathrm{Br}_{\mathrm{y}}^{\mathrm{VSLS}}$ within the same convection scheme. It is important to point out that this uncertainty is likely larger among different models or different versions of the same model when different convective parameterizations are used.

Contrary to conventional wisdom, which holds that the VSLS impact on stratospheric bromine is larger under more intense deep convection, our simulations suggest that the minimum convection condition is favorable for TST of VSLS due to reduced scavenging of soluble product gases under weaker convection. The impact of convection strength on PGI greatly outweighs the impact on SGI with the change in PGI $\sim 10$ times larger than that in SGI.

Acknowledgements. Funding for this research comes from the NNX11AN71G project supported by the NASA ACMAP program. Funding for the DOAS team comes from the German Ministry of Economy (BMWi) (50EE0840), the European Space Agency (ESA-ESRIN: no. RFQ/3-12092/07/I-OL), and the Deutsche Forschungsgemeinschaft, DFG (grants PF-384/5-1 and 384/5-1 and PF384/9-1/2), as well from the EU projects Reconcile (FP7ENV-2008-1-226365) and SHIVA (FP7-ENV-2007-1-226224). We thank Björn-Martin Sinnhuber and the other anonymous reviewer for their very good and constructive comments.

Edited by: P. Haynes

\section{References}

Aschmann, J., Sinnhuber, B.-M., Atlas, E. L., and Schauffler, S. M.: Modeling the transport of very short-lived substances into the tropical upper troposphere and lower stratosphere, Atmos. Chem. Phys., 9, 9237-9247, doi:10.5194/acp-9-9237-2009, 2009.

Aschmann, J., Sinnhuber, B.-M., Chipperfield, M. P., and Hossaini, R.: Impact of deep convection and dehydration on bromine loading in the upper troposphere and lower stratosphere, Atmos. Chem. Phys., 11, 2671-2687, doi:10.5194/acp-11-2671-2011, 2011.

Aschmann, J. and Sinnhuber, B.-M.: Contribution of very shortlived substances to stratospheric bromine loading: uncertainties and constraints, Atmos. Chem. Phys., 13, 1203-1219, doi:10.5194/acp-13-1203-2013, 2013.

Ashfold, M. J., Harris, N. R. P., Atlas, E. L., Manning, A. J., and Pyle, J. A.: Transport of short-lived species into the Tropical Tropopause Layer, Atmos. Chem. Phys., 12, 6309-6322, doi:10.5194/acp-12-6309-2012, 2012.

Balkanski, Y. J., Jacob, D. J., Gardner, G. M., Graustein, W. C., and Turekian, K. K.: Transport and residence times of tropospheric aerosols inferred from a global three-dimensional simulation of ${ }^{210} \mathrm{~Pb}$, J. Geophys. Res., 98, 20573-20586, doi:10.1029/93JD02456, 1993.

Blake, N. J., Blake, D. R., Simpson, I. J., Meinardi, S., Swanson, A. L., Lopez, J. P., Katzenstein, A. S., Barletta, B., Shirai, T., Atlas, E., Sachse, G., Avery, M., Vay., S., Fuelberg, H. E., Kiley, C. M., Kita, K., and Rowland, F. S.: NMHCs and halocarbons in Asian continental outflow during the Transport and Chemical Evolution over the Pacific (TRACE-P) field campaign: comparison with PEM-West B, J. Geophys. Res., 108, 8806, doi:10.1029/2002JD003367, 2003.

Brioude, J., Portmann, R. W., Daniel, J. S., Cooper, O. R., Frost, G. J., Rosenlof, K. H., Granier, C., Ravishankara, A. R., Montzka, S. A., and Stohl, A: Variations in ozone depletion potentials of very short-lived substances with season and emission region, Geophys. Res. Lett., 37, L19804, doi:10.1029/2010GL044856, 2010.

Chin, M., Savoie, D. L., Huebert, B. J., Bandy, A. R., Thornton, D. C., Bates, T. S., Quinn, P. K., Saltzman, E. S., and De Bruyn, W. J.: Atmospheric sulfur cycle in the global model GOCART: Comparison with field observations and regional budgets, J. Geophys. Res., 105, 24689-24712, 2000.

Dorf, M., Bösch, H., Butz, A., Camy-Peyret, C., Chipperfield, M. P., Engel, A., Goutail, F., Grunow, K., Hendrick, F., Hrechanyy, S., Naujokat, B., Pommereau, J.-P., Van Roozendael, M., Sioris, C., Stroh, F., Weidner, F., and Pfeilsticker, K.: Balloon-borne stratospheric $\mathrm{BrO}$ measurements: comparison with Envisat/SCIAMACHY BrO limb profiles, Atmos. Chem. Phys., 6, 2483-2501, doi:10.5194/acp-6-2483-2006, 2006 .

Dorf, M., Butler, J. H., Butz, A., Camy-Peyret, C., Chipperfield, M. P., Kritten, L., Montzka, S. A., Simmes, B., Weidner, F., and Pfeilsticke, K.: Long-term observations of stratospheric bromine reveal slow down in growth, Geophys. Res, Lett., 33, L24803, doi:10.1029/2006GL027714, 2006b.

Dorf, M., Butz, A., Camy-Peyret, C., Chipperfield, M. P., Kritten, L., and Pfeilsticker, K.: Bromine in the tropical troposphere and stratosphere as derived from balloon-borne $\mathrm{BrO}$ observations, Atmos. Chem. Phys., 8, 7265-7271, doi:10.5194/acp-8-72652008, 2008. 
Douglass, A. R. and Kawa, S. R.: Contrast between 1992 and 1997 high-latitude spring Halogen Occultation Experiment observations of lower stratospheric HCl, J. Geophys. Res., 104, 1873918754, doi:10.1029/1999JD900281, 1999.

Dvortsov, V. L., Geller, M. A., Solomon, S., Schauffler, S. M., Atlas, E. L., and Blake, D. R.: Rethinking reactive halogen budgets in the midlatitudes lower stratosphere, Geophys. Res. Lett., 26, 1699- 1702, 1999.

Fueglistaler, S., Wernli, J. and Peter, T.: Tropical troposphere-tostratosphere transport inferred from trajectory calculations, J. Geophys. Res., 109, D03108, doi:10.1029/2003JD04069, 2004.

Fueglistaler, S., Dessler, A. E., Dunkerton, T. J., Folkins, I., Fu, Q., and Mote, P. W.: Tropical tropopause layer, Rev. Geophys., 47, RG1004, doi:10.1029/2008RG000267, 2009.

Gettelman, A. and Forster, P. M. D. F.: A climatology of the tropical tropopause layer, J. Meteorol. Soc. Jpn., 80, 911-924, 2002.

Ginoux, P., Chin, M., Tegen, I., Prospero, J., Holben, B., Dubovik, O., and Lin, S.-J.: Sources and distributions of dust aerosols simulated with the GOCART model, J. Geophys. Res., 106, 2022520273, 2001.

Giorgi, F., and Chameides, W. L.: Rainout lifetimes of highly soluble aerosols and gases as inferred from simulations with a general circulation model, J. Geophys. Res., 91, 14367-14376, 1986.

Hatsushika, H. and Yamazaki, K.: Stratospheric drain over Indonesia and dehydration within the tropical tropopause layer diagnosed by air parcel trajectories, J. Geophys. Res., 108, 4610, doi:10.1029/2002JD002986, 2003.

Hossaini, R., Chipperfield, M. P., Monge-Sanz, B. M., Richards, N. A. D., Atlas, E., and Blake, D. R.: Bromoform and dibromomethane in the tropics: a 3-D model study of chemistry and transport, Atmos. Chem. Phys., 10, 719-735, 2010, http://www.atmos-chem-phys.net/10/719/2010/.

Hossaini, R., Chipperfield, M. P., Feng, W., Breider, T. J., Atlas, E., Montzka, S. A., Miller, B. R., Moore, F., and Elkins, J.: The contribution of natural and anthropogenic very short-lived species to stratospheric bromine, Atmos. Chem. Phys., 12, 371380, doi:10.5194/acp-12-371-2012, 2012a.

Hossaini, R., Chipperfield, M. P., Dhomse, S., Ordonez, C., Saiz-Lopez, A., Abraham, N. L., Archibald, A., Braesicke, P., Telford, P., Warwick, N., Yang, X. and Pyle, J.: Modelling future changes to the stratospheric source gas injection of biogenic bromocarbons, Geophys. Res. Lett., 39, L20813, doi:10.1029/2012GL053401, 2012b.

Hossaini, R., Mantle, H., Chipperfield, M. P., Montzka, S. A., Hamer, P., Ziska, F., Quack, B., Krüger, K., Tegtmeier, S., Atlas, E., Sala, S., Engel, A., Bönisch, H., Keber, T., Oram, D., Mills, G., Ordóñez, C., Saiz-Lopez, A., Warwick, N., Liang, Q., Feng, W., Moore, F., Miller, B. R., Marécal, V., Richards, N. A. D., Dorf, M., and Pfeilsticker, K.: Evaluating global emission inventories of biogenic bromocarbons, Atmos. Chem. Phys., 13, 11819-11838, doi:10.5194/acp-13-11819-2013, 2013.

Hoyle, C. R., Marécal, V., Russo, M. R., Allen, G., Arteta, J., Chemel, C., Chipperfield, M. P., D'Amato, F., Dessens, O., Feng, W., Hamilton, J. F., Harris, N. R. P., Hosking, J. S., Lewis, A. C., Morgenstern, O., Peter, T., Pyle, J. A., Reddmann, T., Richards, N. A. D., Telford, P. J., Tian, W., Viciani, S., Volz-Thomas, A., Wild, O., Yang, X., and Zeng, G.: Representation of tropical deep convection in atmospheric models -
Part 2: Tracer transport, Atmos. Chem. Phys., 11, 8103-8131, doi:10.5194/acp-11-8103-2011, 2011.

Kreycy, S., Camy-Peyret, C., Chipperfield, M. P., Dorf, M., Feng, W., Hossaini, R., Kritten, L., Werner, B., and Pfeilsticker, K.: Atmospheric test of the $J\left(\mathrm{BrONO}_{2}\right) / k_{\mathrm{BrO}}+\mathrm{NO}_{2}$ ratio: implications for total stratospheric Bry and brominemediated ozone loss, Atmos. Chem. Phys., 13, 6263-6274, doi:10.5194/acp-13-6263-2013, 2013.

Kurylo, M. J., and Rodriguez, J. M.: Short-lived ozone related compounds, in Scientific Assessment of Ozone Depletion: 1998, Global Ozone Res. and Monit. Proj., Rep. 44, chap. 2, World Meteorol. Organ., Geneva, Switzerland, 1999.

Levine, J. G., Braesicke, P., Harris, N. R. P., Savage, N. H., and Pyle, J. A.: Pathways and timescales for troposphere-to-stratosphere transport via the tropical tropopause layer and their relevance for very short lived substances, J. Geophys. Res., 112, D04308, doi:10.1029/2005JD006940, 2007.

Levine, J. G., Braesicke, P., Harris, N. R. P., Pyle, J. A.: Seasonal and inter-annual variations in troposphere-to-stratosphere transport from the tropical tropopause layer, Atmos. Chem. Phys. 8, 3689-3703, doi:10.5194/acp-8-3689-2008, 2008.

Liang, Q., Stolarski, R. S., Kawa, S. R., Nielsen, J. E., Douglass, A. R., Rodriguez, J. M., Blake, D. R., Atlas, E. L., and Ott, L. E.: Finding the missing stratospheric Bry: a global modeling study of $\mathrm{CHBr}_{3}$ and $\mathrm{CH}_{2} \mathrm{Br}_{2}$, Atmos. Chem. Phys., 10, 2269-2286, doi:10.5194/acp-10-2269-2010, 2010.

Lin, S.-J.: A “vertically Lagrangian" finite-volume dynamical core for global models, Mon. Weather Rev., 132, 2293-2307, 2004.

Liu, H., Jacob, D. J., Bey, I., and Yantosca, R. M.: Constraints from $210 \mathrm{~Pb}$ and $7 \mathrm{Be}$ on wet deposition and transport in a global three-dimensional chemical tracer model driven by assimilated meteorological fields, J. Geophys. Res., 106, 12109 12128, doi:10.1029/2000JD900839, 2001.

Moorthi, S. and Suarez, M. J.: Relaxed Arakawa-Schubert: A parameterization of moist convection for general circulation models, Mon. Weather Rev., 120, 978-1002, 1992.

Nielsen, J. E. and Douglass, A. R.: A simulation of bromoform's contribution to stratospheric bromine, J. Geophys. Res., 106, 8089-8100, 2001.

Ordóñez, C., Lamarque, J.-F., Tilmes, S., Kinnison, D. E., Atlas, E. L., Blake, D. R., Sousa Santos, G., Brasseur, G., and Saiz-Lopez, A.: Bromine and iodine chemistry in a global chemistry-climate model: description and evaluation of very short-lived oceanic sources, Atmos. Chem. Phys., 12, 14231447, doi:10.5194/acp-12-1423-2012, 2012.

Ott, L. E., Bacmeister, J., Pawson, S., Pickering, K., Stenchikov, G., Suarez, M. Huntriester, H., Loewenstein, M., Lopez, J., and Xueref-Remy, I.: Analysis of Convective Transport and Parameter Sensitivity in a Single Column Version of the Goddard Earth Observation System, Version 5, General Circulation Model, J. Atmos. Sci., 66, 627-646, 2009.

Ott, L. E., Pawson, S., and Bacmeister, J.: An analysis of the impact of convective parameter sensitivity on simulated global atmospheric CO distributions, J. Geophys. Res. 116, D21310, doi:10.1029/2011JD016077, 2011.

Parrella, J. P., Jacob, D. J., Liang, Q., Zhang, Y., Mickley, L. J., Miller, B., Evans, M. J., Yang, X., Pyle, J. A., Theys, N., and Van Roozendael, M., Atmos. Chem. Phys., 12, 6723-6720, doi:10.5194/acp-12-6723-2012, 2012. 
Pyle, J. A., Ashfold, M. J., Harris, N. R. P., Robinson, A. D., Warwick, N. J., Carver, G. D., Gostlow, B., O’Brien, L. M., Manning, A. J., Phang, S. M., Yong, S. E., Leong, K. P., Ung, E. H., and Ong, S.: Bromoform in the tropical boundary layer of the Maritime Continent during OP3, Atmos. Chem. Phys., 11, 529542, doi:10.5194/acp-11-529-2011, 2011.

Randel, W. J. and Jensen, E. J.: Physical processes in the tropical tropopause layer and their role in a changing climate, Nature Geosci., 6, 169-176, doi:10.1038/ngeo1733, 2013.

Reinecker, M. M, Suarez, M. J., Todling, R., Bacmeister, J., Takacs, L., Liu, H.-C., Gu, W., Sienkiewicz, M., Koster, R. D., Gelaro, R., Stajner, I., and Nielsen, J. E.: The GEOS-5 Data Assimilation System-Documentation of Versions 5.0.1, 5.1.0, and 5.2.0, Tech. Rep. 104606 V27, NASA, Greenbelt, MD, 2008.

Rozanov, A., Kühl, S., Doicu, A., McLinden, C., Puķīte, J., Bovensmann, H., Burrows, J. P., Deutschmann, T., Dorf, M., Goutail, F., Grunow, K., Hendrick, F., von Hobe, M., Hrechanyy, S., Lichtenberg, G., Pfeilsticker, K., Pommereau, J. P., Van Roozendael, M., Stroh, F., and Wagner, T.: BrO vertical distributions from SCIAMACHY limb measurements: comparison of algorithms and retrieval results, Atmos. Meas. Tech., 4, 1319-1359, doi:10.5194/amt-4-1319-2011, 2011.

Salawitch, R. J., Canty, T., Kurosu, T., Chance, K., Liang, Q., da Silva, A., Pawson, S., Nielsen, J. E., Rodriguez, J. M., Bhartia, P. K., Liu, X., Huey, L. G., Liao, J., Stickel, R. E., Tanner, D. J., Dibb, J. E., Simpson, W. R., Donohoue, D., Weinheimer, A., Flocke, F., Knapp, D., Montzka, D., Neuman, J. A., Nowak, J. B., Ryerson, T. B., Oltmans, S., Blake, D. R., Atlas, E. L., Kinnison, D. E., Tilmes, S., Pan, L. L., Hendrick, F., Van Roozendael, M., Kreher, K., Johnston, P. V., Gao, R. S., Johnson, B., Bui, T. P., Chen, G., Pierce, R. B., Crawford, J. H., and Jacob, D. J.: A new interpretation of total column BrO during Arctic spring, Geophys. Res. Lett., 37, L21805, doi:10.1029/2010GL043798, 2010.

Sander, S. P., Abbatt, J. P. D., Barker, J. R., Burkholder, J. B., Golden, D. M., Kolb, C. E., Kurylo, M. J., Moortgat, G. K., Wine, P. H., Huie, R. E., Orkin, V. L.: Chemical Kinetics and Photochemical Data for Use in Atmospheric Studies: Evaluation No. 17, JPL Publ. 10-6, Jet Propul. Lab., Pasadena, CA, USA, 2011.

Schauffler, S. M., Atlas, E. L., Blake, D. R., Flocke, F., Lueb, R. A., Lee-Taylor, J. M., Stroud, V., and Travnicek, W.: Distributions of brominated organic compounds in the troposphere and lower stratosphere, J. Geophys. Res., 104, 21513-21535, 1999.

Sinnhuber, B.-M., Rozanov, A., Sheode, N., Afe, O. T., Richter, A., Sinnhuber, M., Wittrock, F., Burrows, J. P., Stiller, G. P., von Clarmann, T., and Linden, A.: Global observations of stratospheric bromine monoxide from SCIAMACHY, Geophys. Res. Lett., 32, L20810, doi:10.1029/2005GL023839, 2005.
Sinnhuber, B.-M. and Folkins, I.: Estimating the contribution of bromoform to stratospheric bromine and its relation to dehydration in the tropical tropopause layer, Atmos. Chem. Phys., 6, 4755-4761, doi:10.5194/acp-6-4755-2006, 2006.

Sioris, C. E., Kovalenko, L. J., McLinden, Salawitch, R. J., Van Roozendael, M., Goutail, F., Dorf, M., Pfeilsticker, K., Chance, K., von Savigny, C., Liu, X. Kurosu, T. P., Pommereau, J.P., Bösch, and Frerick, J.: Latitudinal and vertical distribution of bromine monoxide in the lower stratosphere from Scanning Imaging Absorption Spectrometer for Atmospheric Chartography limb scattering measurements, J. Geophys. Res., 111, D14301, doi:10.1029/2005JD006479, 2006.

Spivakovsky, C. M., Logan, J. A., Montzka, S. A., Balkanski, Y. J., Foreman-Fowler, M., Jones, D. B. A., Horowitz, L. W., Fusco, A. C., Brenninkmeijer, C. A. M., Prather, M. J., Wofsy, S. C., and McElroy, M. B.: Three-dimensional climatological distribution of tropospheric $\mathrm{OH}$ : Update and evaluation, J. Geophys. Res., 105, 8931-8980, 2000.

Sturges, W. T., Oram, D. E., Carpenter, L. J., Penkett, S. A. and Engel, A.: Bromoform as a source of stratospheric bromine, Geophys. Res. Lett., 27, 2081-2084, 2000.

Warwick, N. J., Pyle, J. A., Carver, G. D., Yang, X., Savage, N. H., O'Connor, F. M., and Cox, R. A.: Global modeling of biogenic bromocarbons, J. Geophys. Res., 111, D24305, doi:10.1029/2006JD007264, 2006.

Webster, P. J.: The large scale structure of the tropical atmosphere, General Circulation of the Atmosphere, Academic Press, 235275, 1983.

WMO (2011), Scientific Assessment of Ozone Depletion: 2010, Global Ozone Research and Monitoring Project-Report No. 52, 516 pp., Geneva, Switzerland.

Yang, X., Cox, R. A., Warwick, N. J., Pyle, J. A., Carver, G. D., and O'Connor, F. M.: Tropospheric bromine chemistry and its impacts on ozone: A model study, J. Geophys. Res., 110, D23311, doi:10.1029/2005-JD006244, 2005.

Ziska, F., Quack, B., Abrahamsson, K., Archer, S. D., Atlas, E., Bell, T., Butler, J. H., Carpenter, L. J., Jones, C. E., Harris, N. R. P., Hepach, H., Heumann, K. G., Hughes, C., Kuss, J., Krüger, K., Liss, P., Moore, R. M., Orlikowska, A., Raimund, S., Reeves, C. E., Reifenhäuser, W., Robinson, A. D., Schall, C., Tanhua, T., Tegtmeier, S., Turner, S., Wang, L., Wallace, D., Williams, J., Yamamoto, H., Yvon-Lewis, S., and Yokouchi, Y.: Global sea-to-air flux climatology for bromoform, dibromomethane and methyl iodide, Atmos. Chem. Phys., 13, 8915-8934, doi:10.5194/acp-13-8915-2013, 2013. 